\title{
Neuroprotection Following Concussion: The Potential Role for Cannabidiol
}

\author{
Jyotpal Singh, John Patrick Neary
}

\begin{abstract}
Cannabidiol (CBD) has been generating increasing interest in medicine due to its therapeutic properties and an apparent lack of negative side effects. Research has suggested that high dosages of CBD can be taken acutely and chronically with little to no risk. This review focuses on the neuroprotective effects of a CBD, with an emphasis on its implications for recovering from a mild traumatic brain injury (TBI) or concussion. CBD has been shown to influence the endocannabinoid system, both by affecting cannabinoid receptors and other receptors involved in the endocannabinoid system such as vanilloid receptor 1, adenosine receptors, and 5-hydroxytryptamine via cannabinoid receptor-independent mechanisms. Concussions can result in many physiological consequences, potentially resulting in post-concussion syndrome. While impairments in cerebrovascular and cardiovascular physiology following concussion have been shown, there is unfortunately still no single treatment available to enhance recovery. CBD has been shown to influence the blood brain barrier, brain-derived neurotrophic factors, cognitive capacity, the cerebrovasculature, cardiovascular physiology, and neurogenesis, all of which have been shown to be altered by concussion. CBD can therefore potentially provide treatment to enhance neuroprotection by reducing inflammation, regulating cerebral blood flow, enhancing neurogenesis, and protecting the brain against reactive oxygen species. Doubleblind randomized controlled trials are still required to validate the use of CBD as medication following mild TBIs, such as concussion.
\end{abstract}

RÉSUMÉ : Rôle neuroprotecteur potentiel du cannabidiol à la suite d'une commotion cérébrale. Le cannabidiol suscite un intérêt croissant pour la médecine en raison de ses propriétés thérapeutiques et d'une absence apparente d'effets secondaires négatifs. De plus, des travaux de recherche suggèrent que des doses élevées de cannabidiol peuvent être administrées de façon constante avec peu ou aucun risque. Cette étude entend mettre l'accent sur les effets neuroprotecteurs de ce cannabinoïde présent dans le cannabis et insister plus particulièrement sur ses effets lorsqu'on se remet d'un traumatisme cranio-cérébral (TCC) léger ou d'une commotion cérébrale. On le sait, il a été démontré que le cannabidiol peut influencer le système endocannabinoïde, entre autres les récepteurs cannabinoïdes et d'autres récepteurs tels que les récepteurs vanilloïdes de type 1, les récepteurs de l'adénosine et la sérotonine (5-HT), par l'entremise de mécanismes indépendants. Quant aux commotions cérébrales, elles peuvent entraîner de nombreuses conséquences physiologiques pouvant potentiellement produire un syndrome post-commotionnel. Bien qu'on sache qu'une série de déficiences physiologiques de nature cérébrovasculaire et cardiovasculaire peuvent apparaitre à la suite d'une commotion cérébrale, il n'existe malheureusement pas de traitement unique pour améliorer la récupération des patients. Ceci étant dit, la preuve a été faire que le cannabidiol peut agir sur la barrière hémato-encéphalique, sur les facteurs neurotrophiques dérivés du cerveau, sur la capacité cognitive d'un individu, sur sa « cérébrovasculature », sa physiologie cardiovasculaire et sa neurogénèse, des aspects dont on sait qu'ils sont tous altérés par une commotion cérébrale. En conséquence, il se pourrait que le cannabidiol puisse potentiellement constituer un traitement permettant d'améliorer la neuroprotection des patients en réduisant l'inflammation, en régulant le débit sanguin cérébral, en renforçant la neurogénèse et en protégeant le cerveau contre des dérivés réactifs de l'oxygène. Des essais cliniques randomisés à double insu demeurent toutefois nécessaires afin de confirmer l'utilisation du cannabidiol à titre de médicament à la suite d'un TCC, par exemple une commotion cérébrale.

Keywords: Cannabidiol, Endocannabinoid, Neuroprotection, Concussion, Cerebrovasculature

doi:10.1017/cjn.2020.23

Can J Neurol Sci. 2020; 47: 289-300

\section{INTRODUCTION}

With over 10 million traumatic brain injuries (TBIs) resulting in death or hospitalization occurring annually, ${ }^{1,2}$ there is a need for an effective treatment strategy to recover from these injuries. TBIs can cause difficulty in performing day-to-day activities and even return to normal physiological functioning does not assure that symptoms will clear. ${ }^{3}$ The majority of head injuries, such as concussions, are considered mild traumatic brain injuries (mTBIs) and rarely receive full medical treatment. ${ }^{4}$ Alongside TBIs, there has been an enormous increase in research done in the area of endogenous cannabinoids (endocannabinoids) and the Cannabis sativa and Cannabis indica plants. ${ }^{5}$ Research into phytocannabinoids (plant based), endocannabinoids, and the synthetic development of cannabinoids has hinted at TBI as a potential therapeutic target. ${ }^{1,6}$

Cannabidiol (CBD) is a major nonintoxicating compound found in $C$. sativa and $C$. indica, along with hemp and other plants, ${ }^{7,8}$ and is thought to possess therapeutic potential due to its major neurological and anti-inflammatory properties. ${ }^{9,10}$ It is thought that when CBD is administered alongside other

From the Faculty of Kinesiology \& Health Studies, University of Regina, Regina, Saskatchewan, Canada

Received June 23, 2019. Final Revisions Submitted January 7, 2020. Date of Acceptance January 28, 2020.

Corresponding to: J. Patrick Neary, 3737 Wascana Parkway, Faculty of Kinesiology \& Health Studies, University of Regina, Regina, Saskatchewan S4S 0A2, Canada. Email: Patrick.neary@uregina.ca 
phytocannabinoids, such as tetrahydrocannabinol (THC or $\Delta 9$ THC), there is an entourage effect that elevates the therapeutic properties of both CBD and THC. ${ }^{11-13}$ Human research in this realm in relation to concussion is very limited, presumably due to ethical issues surrounding administration of intoxicating and often illegal compounds such as THC, even if CBD does have the potential to counteract THC psychosis. ${ }^{14,15}$ Numerous animal studies have supported the idea that CBD and THC administered simultaneously can lead to changes in behavioral effects ${ }^{16}$ and altered THC metabolism. ${ }^{17}$ It is also important to note that human studies observing pharmacokinetic and pharmacodynamic effects of CBD are also very limited, ${ }^{18-20}$ although it has been suggested that the maximum measured plasma concentration of $\mathrm{CBD}$ increases in a dose-dependent manner, occurring between 0 and $4 \mathrm{~h}$, depending on administration route. ${ }^{19}$

This review will focus on the neuroprotective effects of cannabinoids, specifically the phytocannabinoid CBD following TBI. Considering the prevalence of the entourage effect, it is also important to discuss what the research suggests regarding the combined effects of endocannabinoids and phytocannabinoids, specifically related to concussion. While an animal model has suggested a role for CBD to regulate glutamate and gammaaminobutyric acid (GABA) ${ }^{21}$ responses following mTBI, the fundamental mechanisms underlying these effects are still not clear, especially when considering human studies.

\section{The Endocannabinoid System}

After the identification and synthesis of $\mathrm{THC}^{22}$ the scientific world expanded much of their knowledge of the cannabis plant constituents. This increase in interest of the exogenous cannabinoids also led to a greater understanding of the endocannabinoid system, which is known to help regulate pain processing and perception, ${ }^{23}$ maintain immune system homeostasis, ${ }^{24}$ and influence cardiovascular functioning. ${ }^{25}$ The endocannabinoid system consists of at least 2 receptors coupled through G-protein inhibition: cannabinoid receptor $1\left(\mathrm{CB}_{1}\right)$ and cannabinoid receptor $2\left(\mathrm{CB}_{2}\right){ }^{26-30}$ Other receptors sensitive to cannabinoids include vanilloid receptor 1 (TRPV1), ${ }^{31,32}$ adenosine receptors, ${ }^{33,34}$ 5-hydroxytryptamine $\left(5-\mathrm{HT}_{1 \mathrm{~A}}\right),{ }^{35,36}$ and G-protein coupled receptors. ${ }^{37}$

The $\mathrm{CB}_{1}$ receptors are most abundant within the central nervous system, located primarily on the axon and synaptic terminals on the neurons, ${ }^{38}$ while the $\mathrm{CB}_{2}$ receptors are much more concentrated within the peripheral nervous system, such as the immune system. ${ }^{38,39}$ Interestingly, $\mathrm{CB}_{2}$ receptors are also present at the brain microglia. ${ }^{40-42} \mathrm{CB}_{2}$ receptors are therefore present at the central nervous system as well, suggesting that the $\mathrm{CB}_{2}$ receptor is not only a peripheral receptor, as implied by earlier studies. ${ }^{26,43,44}$ Specifically, $\mathrm{CB}_{2}$ mRNA expression was found on B Cells in the immune system, ${ }^{44}$ spleen macrophages, ${ }^{26}$ and the thymus. ${ }^{43}$ With $\mathrm{CB}_{1}$ receptors densely concentrated in the central nervous system, ${ }^{45}$ this led to the belief that the $\mathrm{CB}_{1}$ and $\mathrm{CB}_{2}$ receptors can be considered as tissue-selective antigens, ${ }^{44}$ although the presence of $\mathrm{CB}_{2}$ at the microglia does put this statement into question. Microglia activation can result in a release of proinflammatory cytokines and reactive oxygen intermediates ${ }^{46}$ and the presence of the $\mathrm{CB}_{2}$ receptor at the microglia suggests a neuroprotective purpose. For example, $\mathrm{CB}_{2}$ receptor stimulation in $\mathrm{CB}_{1}$ receptor knockout mice produced antinociceptive effects in response to inflammatory pain. ${ }^{47}$ Discussed in more detail in the following section, activation of the $\mathrm{CB}_{1}$ receptor is thought to be responsible for the common psychosis symptoms associated with THC, ${ }^{30}$ while activation of the $\mathrm{CB}_{2}$ receptor can attenuate inflammation and accelerate regeneration in many disease states, ${ }^{41}$ including liver regeneration in an animal model of acute hepatitis ${ }^{48}$ and attenuation of inflammation and tissue injury in an animal model of spinal cord injury. ${ }^{41,49}$ Therefore, the $\mathrm{CB}_{1}$ and $\mathrm{CB}_{2}$ receptors are present in neural and peripheral tissue, suggesting involvement in many physiological processes.

The entourage effect suggests a synergistic effect when different phytocannabinoids are administered together. For assistance across the blood brain barrier, adenosine triphosphatebinding cassette transporters have been shown to aid in THC efflux, ${ }^{50}$ and with CBD's ability to inhibit these transporters, ${ }^{51}$ it is possible that THC may exert its therapeutic influence at the brain for longer periods. ${ }^{52}$ This evidence suggests that the location of $\mathrm{CB}_{2}$ receptors on the microglia can be due to a protective mechanism as THC has been shown to increase $\mathrm{CB}_{2}$ receptor protein expression, thereby attenuating inflammatory responses, an effect which was abolished when $\mathrm{CB}_{2}$ receptor antagonists were introduced. ${ }^{53}$ Furthermore, sustaining high level of THC at the brain can increase its influence on the brain's dopamine system. ${ }^{54}$ Considering that TBIs can impair the nigrostriatal and mesocorticolimbic (mesolimbic and mesocortical) pathways, ${ }^{55}$ THC's ability to potentially increase dopamine firing rates on dopaminergic neurons can aid to alleviate dopamine synthesis, reuptake, and metabolism following TBI. ${ }^{55}$

\section{Concussion Implication AND ENDOCANNABINOID NEUROPHYSIOLOGY}

\section{Introduction to Concussion}

Concussion or mTBI-related injuries have been a growing issue, both in adults and youths. ${ }^{56-59}$ While return to baseline after 3 weeks is common in individuals aged 5-14 years, ${ }^{58}$ post-concussion syndrome (concussion-like symptoms lasting over 3 months following mTBI) has been shown to persist for over 6 months in $40 \%$ of mTBI patients. ${ }^{60}$ Post-concussion syndrome can have negative effects on the individual's day-today activities, as shown through its negative associations with health-related quality of life, assessed by the 36-item Short-Form Health Survey and Perceived Quality of Life Scale. ${ }^{60}$ Persistence of one symptom was much more common than multiple symptoms (with headache, fatigue, forgetfulness, and poor concentration among the most common), ${ }^{61,62}$ and being female was a significant predictor of symptoms lasting 12 months post injury. ${ }^{62}$

Concussion can initiate a neurometabolic cascade, ${ }^{63}$ which can lead to an energy crisis, thereby impairing cerebral blood flow, ${ }^{64}$ increasing intracellular calcium $\left(\mathrm{Ca}^{2+}\right)$ levels ${ }^{63,65}$ and disrupting autonomic functioning, ${ }^{66,67}$ among other physiological consequences (Figure 1). ${ }^{63,66,68-76}$ mTBIs generally occur due to rotational or twisting forces (accelerations or decelerations) ${ }^{77,78}$ of the brain within the skull, thereby resulting in a disruption in homeostasis. In comparison, the endocannabinoid system is thought to have neuroprotective properties, ${ }^{79,80}$ which could therefore ameliorate these disturbances in physiological homeostasis. This may partly be due to the fact that the endocannabinoids are retrograde messengers with the ability to cause depolarization-induced suppression of inhibition. ${ }^{81}$ Once neurotransmitters are released from the presynaptic neuron, they bind to the postsynaptic receptors to 


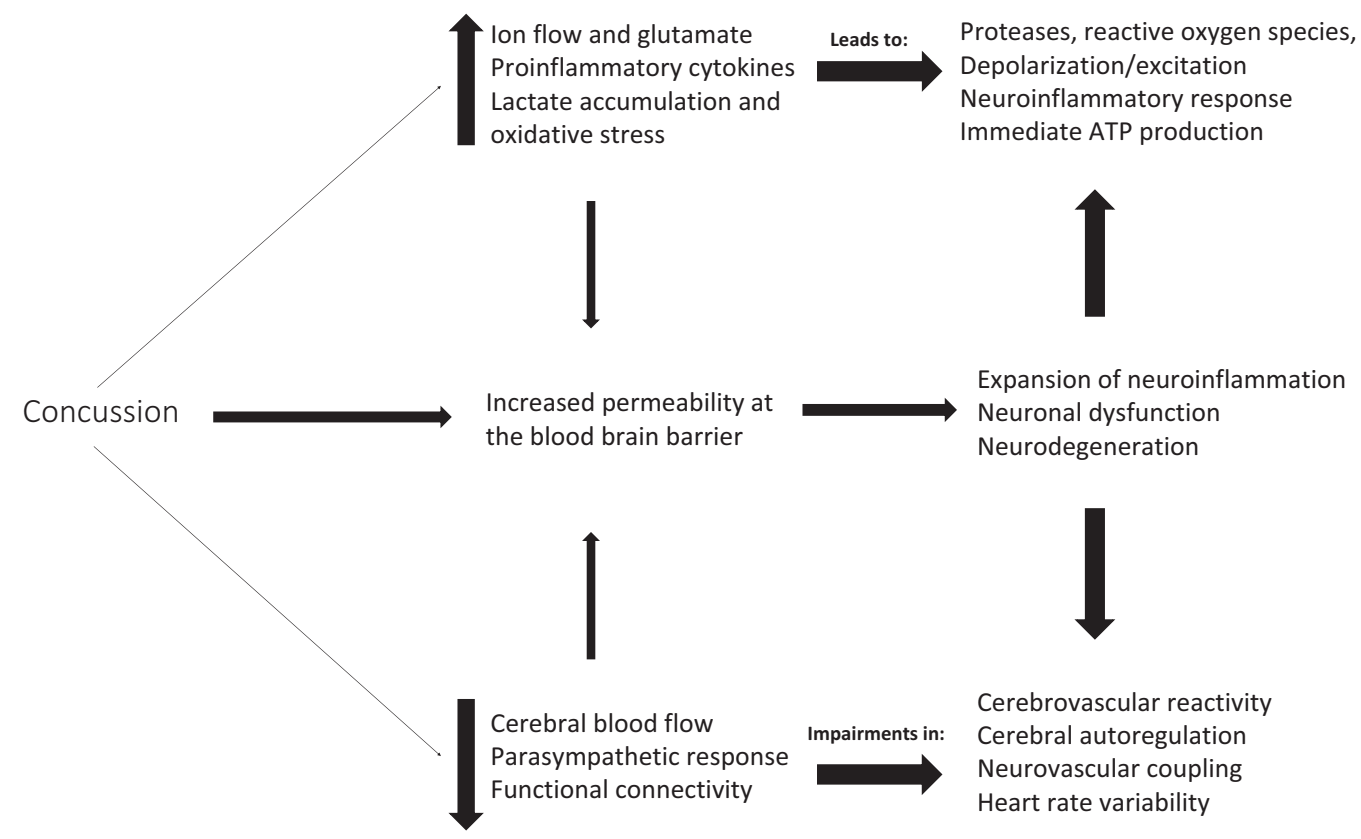

Figure 1: Overview of physiological consequences following concussion.

induce either excitatory or inhibitory postsynaptic potentials. This binding to the postsynaptic receptors allows for entry of $\mathrm{Ca}^{2+}$ into the cell, leading to the activation of phospholipase (PL) and diacylglycerol lipase (DAGL). ${ }^{82}$ Activation of PL and DAGL in combination with arachidonic acid leads to biosynthesis of $\mathrm{N}$-arachidonylethanolamine (also called anandamide; AEA) and 2-arachidonoyl glycerol (2-AG) ${ }^{83-85}$ These endocannabinoids are thought to be produced in vivo where increased intracellular $\mathrm{Ca}^{2+}$ concentration is the major trigger for synthesis. ${ }^{86}$ The endocannabinoid ligands, such as AEA and 2-AG, ${ }^{29}$ are released from cells in a stimulus-dependent manner by cleavage of membrane lipid precursors. ${ }^{87-89}$ These endocannabinoids travel back to the presynaptic neuron and bind to the $\mathrm{CB}_{1}$ receptors which causes a decrease in presynaptic neurotransmitter release across the synaptic cleft. This is done by inhibition of adenylate cyclase (leading to a decrease in sodium $\left(\mathrm{Na}^{+}\right)$inflow) and calcium channels, along with activation of the potassium $\left(\mathrm{K}^{+}\right)$channels, ${ }^{81}$ thus potentially leading to hyperpolarization as depolarizationinduced suppression of inhibition decreases the frequency of miniature inhibitory postsynaptic currents. Taken together, these changes in ionic balance can increase the percentage of synaptic failures. ${ }^{81}$

The endocannabinoid ligands are synthesized by the body from arachidonic acid of membrane phospholipids ${ }^{90}$ in response to pain, inflammation, anxiety, emotional and physical stressors, and pathological conditions. Completion of the endocannabinoid signaling is thought to require cellular reuptake through a carriermediated transport process followed by enzymatic degradation by enzyme fatty acid amide hydrolase primarily for $\mathrm{AEA}^{91}$ and monoacylglycerol lipase for 2-AG. ${ }^{90}$ The $\mathrm{Ca}^{2+}$-dependent synthesis and release of endocannabinoids for its retrograde mechanism could have a significant role in protecting the body by limiting overstimulation, such as protection against the energy crisis which occurs during the neurometabolic cascade following a mTBI. ${ }^{63}$

\section{Cannabidiol Implications for Neuroprotection following} Concussion

CBD is a phytocannabinoid found in the $C$. sativa and hemp plant that is well known for its therapeutic potential but is devoid of psychosis. ${ }^{92,93}$ Phytocannabinoids, including CBD, are also known to act on other receptors aside from the $\mathrm{CB}_{1}$ and $\mathrm{CB}_{2}$ receptors in the body (Table 1). CBD can inhibit fatty acid amide hydrolase, thereby inhibiting the enzymatic hydrolysis and uptake of $\mathrm{AEA}^{101}$ from the synapse. This implies that CBD can therefore indirectly influence the effects on AEA in the endocannabinoid system, possibly allowing for sustained neuroprotective effects of AEA, ${ }^{102,103}$ such as influencing $\mathrm{CB}_{2}$ receptors to alleviate lipopolysaccharide-induced neuroinflammation. ${ }^{104}$

TRPV1 is a ligand-gated ion channel and acts on afferent neurons where it is expressed both presynaptically, and postsynaptically. This receptor is involved in the sensation of pain and thermal hyperalgesia. ${ }^{105} \mathrm{CBD}$ can function as a weak TRPV-1 agonist, which may explain its therapeutic ability in neuropathic pain, ${ }^{94,101}$ as $10 \mathrm{mg} \cdot \mathrm{kg}^{-1}$ of CBD administered to rats with acute inflammation showed an antihyperalgesic response. ${ }^{94}$ Research by Benyó et $\mathrm{al}^{106}$ highlights that the activation of TRPV1 is known to control vascular responses, thus hinting at the idea of CBD having different actions within the cerebral vasculature. Furthermore, Benyó et al suggest that phytocannabinoids and endocannabinoids have the ability to directly influence cerebrovascular resistance and blood perfusion of the brain ${ }^{106}$ and that all cerebrovascular control pathways contain cells capable of being modulated by the different forms of cannabinoids. Considering that concussions can impair cerebrovascular reactivity, ${ }^{73,107,108}$ it is possible that CBD's influence on TRPV1 can protect against these changes.

Another group of receptors upon which CBD is known to act are adenosine receptors, such as A2a receptors. These receptors can downregulate the release of other neurotransmitters such as dopamine and glutamate, and CBD is thought to increase brain 
Table 1: Non $\mathrm{CB}_{1}$ and $\mathrm{CB}_{2}$ receptors stimulated by $\mathrm{CBD}$ and their relevance to concussion pathophysiology

\begin{tabular}{|c|c|c|c|c|}
\hline Receptor & Implications for concussion & Dose and model & Model of injury & Reference \\
\hline TRPV1 & $\begin{array}{l}\text { Antihyperalgesic effect in } \\
\text { response to inflammation }\end{array}$ & $\begin{array}{l}\text { Male Wistar rats with acute } \\
\text { inflammation; CBD } 10 \mathrm{mg} \cdot \mathrm{kg}^{-1}\end{array}$ & $\begin{array}{l}\text { Intraplantar injection of } 0.1 \mathrm{ml} \\
\text { carrageenan }(1 \%) \text { in saline }\end{array}$ & Costa et al. ${ }^{94}$ \\
\hline \multirow[t]{2}{*}{$5-\mathrm{HT}_{1 \mathrm{~A}}$} & $\begin{array}{l}\text { Decrease in excitotoxicity, } \\
\text { inflammation, and oxidative stress }\end{array}$ & $\begin{array}{l}\text { 1-2-day-old male piglets; CBD } \\
1 \mathrm{mg} \cdot \mathrm{kg}^{-1}\end{array}$ & $\begin{array}{l}\text { Interrupted carotid blood flow and } \\
\text { reduced inspired oxygen fraction } \\
\text { to } 10 \% \text { to induce } 30 \text {-min long } \\
\text { cerebral hypoxic ischemia }\end{array}$ & Pazos et al. ${ }^{95}$ \\
\hline & Increase in cerebral blood flow & $\begin{array}{l}\text { Male mice; CBD } 0.1 \text { to } \\
10 \mathrm{mg} \cdot \mathrm{kg}^{-1}\end{array}$ & $\begin{array}{l}\text { Occlusion to the middle cerebral } \\
\text { artery }\end{array}$ & Mishima et al. ${ }^{96}$ \\
\hline \multirow[t]{2}{*}{$\operatorname{PPAR} \gamma$} & $\begin{array}{l}\text { Suppress the increase in the blood } \\
\text { brain barrier permeability (also an } \\
\text { effect of } 5-\mathrm{HT}_{1 \mathrm{~A}} \text { ) }\end{array}$ & $\begin{array}{l}\text { Human brain microvascular } \\
\text { endothelial cells and human } \\
\text { astrocytes; CBD } 100 \mathrm{nM}, 1 \mu \mathrm{M} \text {, } \\
\text { and } 10 \mu \mathrm{M}\end{array}$ & - & Hind et al. $^{97}$ \\
\hline & $\begin{array}{l}\text { Promotion of hippocampal } \\
\text { neurogenesis and reduction in } \\
\text { inflammatory biomarkers }\end{array}$ & $\begin{array}{l}\text { Adult male Sprague-Dawley rats; } \\
\text { CBD } 10 \mathrm{mg} \cdot \mathrm{kg}^{-1}\end{array}$ & $\begin{array}{l}\text { Intrahippocampal injection of } \\
\text { fibrillar } A \beta(1-42) \text { peptide }\end{array}$ & Esposito et al. ${ }^{98}$ \\
\hline \multirow[t]{2}{*}{$\mathrm{A} 2 \mathrm{a}$} & $\begin{array}{l}\text { Downregulate inflammatory } \\
\text { biomarkers and attenuate } \\
\text { microglia activation }\end{array}$ & Female mice; CBD $5 \mathrm{mg} \cdot \mathrm{kg}^{-1}$ & $\begin{array}{l}\text { Intracerebral inoculation in the } \\
\text { right hemisphere with plaque- } \\
\text { forming units }\end{array}$ & Mecha et al. ${ }^{99}$ \\
\hline & $\begin{array}{l}\text { Reduce inflammatory biomarkers } \\
\text { and glutamate in hypoxic- } \\
\text { ischemia }\end{array}$ & $\begin{array}{l}\text { Forebrain of 7-to-10-day-old } \\
\text { C57BL6 mice; CBD } 0.1 \text { to } \\
1000 \mu \mathrm{M}\end{array}$ & $\begin{array}{l}\text { Forebrain slices from } 7 \text {-to-10-day- } \\
\text { old subjected to oxygen-glucose } \\
\text { deprivation }\end{array}$ & Castillo et al. ${ }^{100}$ \\
\hline
\end{tabular}

TRPV1 = vanilloid receptor $1 ; \mathrm{A} 2 \mathrm{a}=$ adenosine receptor; $5-\mathrm{HT}_{1 \mathrm{~A}}=5$-hydroxytryptamine; $\mathrm{PPAR} \gamma=$ peroxisome proliferator-activated receptor gamma; $\mathrm{CBD}=$ cannabidiol.

adenosine levels by reducing adenosine reuptake. ${ }^{9}$ Furthermore, CBD-mediated activation of $\mathrm{A} 2 \mathrm{a}$ receptors may also allow for increased anti-inflammatory effects, further increasing CBD's potential for enhancing neuroprotection. ${ }^{100}$ Indeed, CBD was shown to downregulate inflammatory biomarkers and attenuate microglia activation in a viral mouse model of multiple sclerosis by interacting with A2a receptors. ${ }^{99}$ Finally, it was suggested that $\mathrm{CBD}$ can blunt the THC-induced cognitive and memory impairments in an A2a receptor-dependent manner, ${ }^{109}$ as shown by $\mathrm{A} 2 \mathrm{a}$ receptor knockout mice performance in a two-object recognition test. ${ }^{109}$

$\mathrm{CBD}$ is also known to act directly upon the $5-\mathrm{HT}_{1 \mathrm{~A}}$ receptor, which is found in the brain in large concentrations, with large densities at the prefrontal cortex, hippocampus, and amygdala. ${ }^{110,111} \mathrm{CBD}$ has been shown to exhibit a high potency for this receptor and serves as an agonist, to further stimulate the receptor's properties of decreasing anxiety, pain, and headaches. 5-HT ${ }_{1 \mathrm{~A}}$ is a G-protein-coupled serotonin receptor, which further suggests the potential of $\mathrm{CBD}$ to provide therapeutic benefits, ${ }^{35}$ similar to those of serotonin itself. For example, it was found that CBD can enhance both serotonergic and glutamate cortical signaling in a mouse model, possibly allowing for rapid-acting antidepressant-like effects. ${ }^{112}$ Furthermore, human cell culture, rat, and pig research has also shown CBD to be neuroprotective by inhibiting the reuptake of $5 \mathrm{HT},{ }^{35,95}$ resulting in decreased excitotoxicity, inflammation, and oxidative stress. $^{95}$

Peroxisome proliferator-activated receptor (PPAR) gamma $(\gamma)$ is also thought to be influenced by phytocannabinoids to produce therapeutic effects. ${ }^{113}$ PPARs are nuclear receptor proteins that function as transcription factors and are essential in the body's ability to regulate energy homeostasis and metabolic function. ${ }^{114}$
As such, their involvement becomes increasingly important in stabilizing cell homeostasis. For example, it was shown that CBD suppresses the increased permeability of the blood brain barrier associated with oxygen-glucose deprivation by PPAR $\gamma$ and 5-HT $1 \mathrm{~A}$ activation. ${ }^{97,113}$ This was done using human brain microvascular endothelial cells and human astrocytes, ${ }^{97}$ providing a valuable in vitro point of view rather than an animal model. In relation to other neurodegenerative disorders, cell culture research has shown that CBD reduces $\beta$-amyloid expression ${ }^{113,115}$ and can possibly induce apoptosis in some forms of cancer cells, such as lung tumor cells, ${ }^{113,116}$ via PPAR activation. PPAR $\gamma$ is thought to inhibit the expression of inflammatory cytokines, ${ }^{114,117}$ suggesting possible CBD and PPAR $\gamma$ synergy to further regulate inflammation. This was further shown by CBD's inhibition of necrosis factor kappa b, nitric oxide, tumor necrosis factor alpha, and interleukin 1 beta, along with promoting hippocampal neurogenesis in a rat model. It is important to note that CBD's neuroprotective effects were completely abolished after introduction of a PPAR $\gamma$ antagonist (GW9662). ${ }^{98}$

Finally, a receptor initially known as the endothelial cannabinoid receptor, now thought to be G-protein-coupled receptor $18,{ }^{118,119}$ also serves as a receptor at which abnormal CBD (ABN-CBD), a synthetic CBD product, was shown to react. ${ }^{118-120}$ This receptor is believed to be in existence as administration of CBD to mice lacking the cannabinoid receptors still resulted in hypotension and endothelium-dependent mesenteric vasodilation, yet administration of a $\mathrm{CB}_{1}$ antagonist was shown to block the CBD effect. ${ }^{106}$ It is therefore possible that $\mathrm{CBD}$ can help to regulate cerebral blood flow due to its influence on vasomotor control, meaning that the endothelial cannabinoid receptor and G-protein-coupled receptors stimulated by CBD can mediate neuroprotective effects and regulate cell migration. 
Concussion can result in a cascade of pro- and anti-inflammatory cytokines, ${ }^{121}$ ionic imbalance, ${ }^{63}$ increased lactate accumulation due to increased glycolysis and oxidative stress, ${ }^{122,123}$ and impaired cerebral blood flow. ${ }^{73}$ Through its influences on the cerebrovasculature, its anti-inflammatory properties, and its neuroprotective properties, CBD can theoretically help to reduce impairments following concussion. Furthermore, to control for the calcium sequestration and ionic inflow, ${ }^{69}$ it has been suggested that $\mathrm{CBD}$ can regulate $\mathrm{Ca}^{2+}$ homeostasis against mitochondrial dysfunction and toxins, and $\mathrm{Ca}^{2+}$ dysregulation, as shown in tissue cultures of rat pups. ${ }^{124}$

Due to its neuroprotective capabilities and its lack of intoxicating side effects, CBD shows promising potential in helping individuals with TBIs. Mice induced with bilateral common carotid artery occlusion were administered $10 \mathrm{mg} \cdot \mathrm{kg}^{-1}$ CBD which attenuated hippocampal neurodegeneration and white matter injury, increased hippocampal brain-derived neurotrophic factor protein levels, stimulated neurogenesis, and promoted dendritic restructuring. ${ }^{125}$ Furthermore, CBD administration to mice both before and after occlusion of the middle cerebral artery showed that CBD suppressed the impairment in cerebral blood flow by the failure of cerebral microcirculation after reperfusion, providing further evidence of CBD's neuroprotective properties. ${ }^{126}$ Adding to this evidence of neuroprotective potential, CBD administration to piglets exposed to acute hypoxia-ischemia increased the brain activity post-ischemia back to normal as shown by brain electrical activity, cerebral tissue oxygenation, and neurobehavioral responses, such as motor performance. ${ }^{127}$

\section{Blood Brain Barrier}

Concussions can alter cerebrovascular actions by disrupting the blood brain barrier integrity. ${ }^{128}$ Cannabinoids, specifically 2-AG and dexanabinol, a synthetic cannabinoid also known as HU-211, have been shown to decrease proinflammatory cytokines such as tumor necrosis factor-alpha ${ }^{129}$ and necrosis factor kappa $b .{ }^{130}$ Cytokines have been shown to overexpress following concussion, ${ }^{121}$ which can lead to a heightened sensitivity for disease, such as multiple sclerosis or Alzheimer's, at the blood brain barrier. ${ }^{131}$ Furthermore, head injuries tend to enhance the activity of water-soluble antioxidants in the brain. ${ }^{132}$ This occurs along with an increase in $2-\mathrm{AG},{ }^{133}$ which can further increase the levels of the water-soluble antioxidants, ${ }^{134}$ suggesting a regulator ability for the endocannabinoid in neuroprotection with the blood brain barrier, ${ }^{133}$ especially as synthetic $2-\mathrm{AG}$ administration in a mouse model resulted in reduced brain edema, infarct volume, and hippocampal cell death. ${ }^{133}$ The blood brain barrier controls the amount of material transported into the brain, and in combination with the $\mathrm{CB}_{1}$ and $\mathrm{CB}_{2}$ receptors, it can limit and protect the brain against the influx of neurotoxins, immune cells, and macromolecules, ${ }^{135}$ thus allowing maintenance of an optimal extracellular environment in the brain. ${ }^{106}$ This allows for prevention of apoptosis, glia cell activation, and scar tissue formation, among other symptoms caused by these substances. While $\mathrm{CB}_{1}$ and $\mathrm{CB}_{2}$ receptors are involved in the blood brain barrier, 2-AG is effective as a full $\mathrm{CB}$ receptor agonist, ${ }^{136,137}$ which may help explain its anti-inflammatory propertie ${ }^{39,100}$ due to its influence on the $\mathrm{CB}_{2}$ receptor. CBD's lipophilic properties allow it to easily pass the blood brain barrier. ${ }^{9}$ While research pertaining to CBD's influence at the blood brain barrier in humans is limited, it has been shown that CBD can preserve the barrier's integrity (permeability), possibly by protecting against the loss of tight junction proteins by acting on PPAR $\gamma$ and 5-HT1A receptors. ${ }^{97,138}$

Adding to CBD's neuroprotective properties, oxidative stress is greatly modulated by CBD as well. ${ }^{139-142}$ Following a TBI, there is an increase in free radical production, such as reactive oxygen species. ${ }^{143,144}$ Under oxidative stress, the protective effect of CBD is thought to be mediated by a decrease in reactive oxygen species production. ${ }^{140}$ This can be due to the electrophilic aromatic molecular region and hydroxyl groups of CBD, potentially allowing it to act as an antioxidant itself. ${ }^{145-147}$ Post TBI, $\mathrm{N}$-methyl-d-aspartate (NMDA) receptor binding by glutamate allows for intracellular accumulation of $\mathrm{Ca}^{2+}$, causing cellular damage via proteases, reactive oxygen species, and mitochondrial impairment. ${ }^{69,70}$ NMDA-induced retinal neurotoxicity in rats was also shown to be treated by intravenous injection of CBD to the eye at $2 \mathrm{mg} \cdot \mathrm{kg}^{-1}$, which further shows the antioxidative properties of $\mathrm{CBD}$, as it reduced both oxidative and nitrative stress. ${ }^{148}$

\section{Brain-Derived Neurotrophic Factors}

Brain-derived neurotrophic factors (BDNF) is a protein that promotes the survival of nerve cells. It is known to increase the frequency of miniature excitatory postsynaptic currents, possibly strengthening excitatory, glutamatergic synapses and weakening inhibitory, GABAergic synapses. ${ }^{149,150}$ In cases involving encephalopathy, the administration of $5 \mathrm{mg} \cdot \mathrm{kg}^{-1} \mathrm{CBD}$ was shown to help restore $\mathrm{BDNF}$ levels in mice through the activation of the $5-\mathrm{HT}_{1 \mathrm{~A}}$ receptor. ${ }^{151}$ Furthermore, withdrawal from amphetamines can diminish BDNF levels due to oxidative stress. ${ }^{152}$ This decrease in BDNF has been shown to be blocked by the administration of $60 \mathrm{mg} \cdot \mathrm{kg}^{-1}$ dosages of CBD in a rat model, ${ }^{153,154}$ suggesting that CBD may have a great potential for aiding in addiction recovery and attenuate reductions in BDNF levels. Finally, $30 \mathrm{mg} \cdot \mathrm{kg}^{-1}$ dosages of CBD have been shown to upregulate BDNF following cerebral malaria in a rodent model through the nitric synthase pathway. ${ }^{155}$ This ability of CBD to increase BDNF expression can suggest an important role in neuroprotection, leading to decreased neuronal damage. ${ }^{153} \mathrm{BDNF}$ is also thought to enhance neurogenesis ${ }^{149}$ further suggesting CBD's restorative potential. At the prefrontal cortex and hippocampus, CBD was shown to elevate BDNF levels, resulting in sustained antidepressant-like effects in mice. ${ }^{156}$ Considering that BDNF levels can be impaired following TBI in humans ${ }^{157,158}$ and there is a correlation between BDNF serum levels and cognitive impairments, ${ }^{159}$ it is possible that CBD administration post-concussion can further aid in the recovery process.

\section{Cognitive Capacity}

Cognitive capacity is the total amount of information the brain can retain at any moment. Functional magnetic resonance imaging (fMRI) is a neuroimaging method used to measure brain activity by observing correlations relative to blood flow, thus allowing measurements of neural mechanisms of cognitive capacities. ${ }^{160}$ Using this fMRI technique, for example, it was found that THC and CBD have distinct effects on regional brain activation, ${ }^{161}$ sometimes even completely opposite effects ${ }^{161,162}$ when $10 \mathrm{mg}$ THC, $600 \mathrm{mg}$ CBD, or placebo capsules were 
administered to 14 healthy human volunteers. This study found that found that THC decreased the activation of bilateral temporal cortices during auditory processing and was associated with increases in anxiety, intoxication, and positive psychotic symptoms. It also influenced visual processing. In contrast, CBD administration did not have any reductive effects on areas such as visual processing and showed no significant symptomatic effects such as psychotic symptoms and increases in anxiety, ${ }^{161,162}$ suggesting that CBD alone can provide therapeutic benefits without the intoxication of THC.

Interestingly, THC and CBD have also shown opposite effects on cognition-related brain activation. It has been suggested that the harmful effect of cannabis might be driven by high THC/low CBD compositions, ${ }^{163}$ as shown by poor performances on verbal memory task, ${ }^{164}$ reduced emotional processing accuracy, ${ }^{165}$ and poorer verbal memory performance. ${ }^{166}$ Combination of CBD and THC allows a reduction in the psychotic effects of THC, and thus CBD is able to partially prevent the detrimental effects of THC on working memory. ${ }^{163,166}$ Finally, higher THC concentrations found in hair strands were shown to negatively impact memory and psychological well-being, whereas lower psychosis-like symptoms were found in individuals with higher CBD concentrations in their hair, ${ }^{167}$ further showing CBD's nonintoxicating therapeutic influence.

\section{Cerebrovasculature}

CBD administration following TBI possesses strong potential to significantly reduce inflammation via the reduction in microglia activation and proinflammatory cytokines. ${ }^{90,134,153}$ As discussed earlier, during brain trauma, the endocannabinoid system is activated by the rise in intracellular $\mathrm{Ca}^{2+}$. Activation of the endocannabinoid system suggests that it is part of the compensatory repair mechanism for the brain. ${ }^{168}$ Since cerebral blood flow is tightly regulated by myogenic, endothelial, metabolic, and neural mechanisms, all major cell types involved in cerebrovascular control pathways are capable of synthesizing endocannabinoids. ${ }^{106}$ Finally, CBD administration has been shown to increase cerebral blood flow following middle cerebral artery occlusion by action on $5-\mathrm{HT}_{1 \mathrm{~A}}$ receptors. ${ }^{96,169}$ As such, it is logical to hypothesize that the endocannabinoid system modulates the regulation of cerebral circulation ${ }^{170}$ under both physiological and pathophysiological conditions. ${ }^{106}$

Regulation of blood flow following a TBI can be beneficial in assuring adequate nutrient supply to areas of altered metabolic activity. This compensatory phenomenon in healthy individuals is internally regulated through a mechanism known as neurovascular coupling. While no direct studies have shown CBD's influence on this mechanism, the role of the endocannabinoid system in cerebral circulation $^{106}$ and the presence of TRPV1 at the sensory vagal afferent neurons and the tunica of blood vessels ${ }^{25}$ give CBD the cardioprotective potential. Concussion may lead to changes in the neurovascular coupling response, ${ }^{67,76,171}$ and CBD has been shown to regulate cerebral blood flow ${ }^{172}$ and influence pial vessel responses by regulating vascular effects in combination with protecting the blood brain barrier. ${ }^{173}$ Keeping in mind that the cannabinoid receptors and TRPV1 are located at the cerebrovasculature, ${ }^{106}$ CBD's ability to sustain high AEA levels by inhibiting fatty acid amide hydrolase ${ }^{174}$ suggests an indirect effect on $\mathrm{CB}$ receptors. Further stimulation of $\mathrm{CB}_{2}$ receptors by AEA can allow for regulation of nitric oxide, thereby potentially suppressing neuroinflammatory reactions, ${ }^{104}$ which suggests great potential in combination with the $\mathrm{CB}_{1}$ receptor stimulation to promote neuroprotection, as the neuroprotective effects of AEA are also mediated by the $\mathrm{CB}_{1}$ receptor. ${ }^{102}$

Finally, functional connectivity impairments have also been shown following concussion. Specifically, patients with persistent post-concussion symptoms have reduced connectivity and reduced coherence during memory tasks, ${ }^{175}$ and reduced connectivity in the default mode network during resting states has also been shown in subacute patients and patients assessed less than 3 weeks post injury. ${ }^{176,177}$ Human research has shown that THC intake resulted in decreases in the default mode network activation (a large scale of interacting brain regions known to have activity highly correlated with each other, especially during task disengagement ${ }^{178}$ ), whereas a combination of THC and CBD attenuated the disruption in this network seen when THC is taken alone. ${ }^{179}$ Patients with autism spectrum disorder were administered $600 \mathrm{mg}$ of CBD and they also showed changes in functional connectivity as assessed by the fractional amplitude of low-frequency fluctuations. ${ }^{180}$ While the direct underlying mechanism by which CBD regulates functional connectivity requires more research, there is a clear therapeutic effect on functional connectivity following CBD intake.

\section{Dopaminergic Impairments following Concussion}

TBIs can result in impaired dopamine signaling at the brain. Specifically, the long axonal projections in the dopaminergic nigrostriatal and mesocorticolimbic pathways can be disrupted due to mechanical damage, which induces oxidative stress, axonal damage, and postsynaptic neuron impairments. ${ }^{55,181}$ Following these acute changes, sustained dopamine impairments due to TBI results in BDNF reduction, increase in inflammatory processes, and metabolic dysregulation. ${ }^{55}$ In combination with epigenetic effects and mitochondrial dysregulation, ${ }^{55,182}$ TBIs can therefore result in impairments in dopamine synthesis and metabolism. ${ }^{55}$ Rodent studies have shown that THC can result in increased dopamine neuron firing rates, while human studies have shown mixed responses. ${ }^{54} \mathrm{CBD}$ has been shown to be a partial agonist at dopamine receptors in rat striatal tissue, potentially explaining some of its antipsychotic effects. ${ }^{183}$ Furthermore, in a rat model of Parkinson's disease, CBD was shown to attenuate loss of dopaminergic neurons and microglia activation. ${ }^{184,185} \mathrm{CBD}$ and THC both seem to aid in neuroprotection of dopaminergic pathways following mTBI and TBI.

\section{Cardiovascular Physiology in Relation to Concussion}

CBD has also been shown to exert its protective influences over the cardiovascular system. For example, diabetes is known to cause dysfunction and cardiac autonomic abnormalities ${ }^{186}$ by mechanisms such as hyperglycemia-induced overproduction of reactive oxygen species and impaired antioxidant enzyme activities. Administration of ABN-CBD has been shown to attenuate these effects in rats and even promote vagal responses (such as decreased heart rate and mean arterial pressure), supported by a high frequency increase in the electrocardiogram (ECG) R-R index spectral analysis. ${ }^{187}$ It is important to note that heart rate variability impairments have been noted following concussion, ${ }^{74,188,189}$ although the specific physiological mechanism(s) is still unknown. 
As concussion can occur due to any transient neurologic dysfunction resulting from a biomechanical force, ${ }^{63}$ an injury leading to autonomic dysfunction may further lead to changes in heart rate variability. Furthermore, decreased global heart rate variability is also thought to be related to arrhythmic mortality. ${ }^{190-192}$ CBD's ability to reduce arrhythmic events (ventricular tachycardia and total length of arrhythmias) ${ }^{193}$ suggests further potential to treat cardiovascular complications arising from concussion. It has been shown that there are some changes in heart rate variability when getting the participant to exercise, ${ }^{66,188}$ but the data are still unclear as to what the changes imply. Regardless, it is clear is that dysfunction occurs following concussion, and considering the effect of ABN-CBD to influence endothelial cannabinoid receptors, it follows that phytocannabinoids can potentially help regulate the cardiovascular system following dysfunction.

\section{Neurogenesis}

Following mTBI, neuronal cell death is usually a result of increased intracellular $\mathrm{Ca}^{2+}$ concentration, as this increases glutamate release across the synapse, activation of NMDA receptors, and thereby increasing $\mathrm{Ca}^{2+}$ concentration. This can further lead to increased enzymatic activity, specifically enzymes which can induce apoptosis. The ability of phytocannabinoids and endocannabinoids to inhibit N- and P/Q-type calcium channels ${ }^{194}$ and the ability of CBD to induce a hyperpolarizing shift in the steady state inactivation potentials of the T-type calcium channels ${ }^{195}$ imply that there is potential for CBD to aid in neurogenesis and protection against neurodegenerative processes.

Endocannabinoids are known to be produced by neural progenitor cells which can stimulate proliferation at the hippocampal and subventricular zones via $\mathrm{CB}_{1}$ receptors, as documented by neurosphere generation. ${ }^{196} \mathrm{CBD}$ has been suggested to have a restorative effect on regions of the hippocampus which may be damaged due to prolonged cannabis use. ${ }^{197}$ Furthermore, mice with knocked-out fatty acid amide hydrolase enzyme express a higher concentration of 2-AG, which has been shown to induce astrogliogenesis. ${ }^{198}$ The mechanism behind CBD's ability to regulate neurogenesis seems to involve the mitogen-activated protein kinase (MAPK) pathway, activation of which allows neural progenitor cell proliferation, whereas the $\mathrm{CB}_{1}$ receptor -mediated inhibition of the proliferation is due to the attenuation of sustained MAPK activity. ${ }^{196,199}$ These results suggest that CBD and the endocannabinoids themselves can be key compounds in neurogenesis.

\section{Gaps AND Limitations in the Literature}

While there is strong preclinical and basic science evidence to show that $\mathrm{CBD}$ has the potential to be a candidate for concussion treatment, it is important to note that no double-blind, randomized controlled trials have been completed to show CBD as an efficacious medication following these mTBIs. As our review suggests, there is substantial evidence shown through rodent models which does imply that there are benefits for administration of CBD for concussion recovery. Following this note, there is a clinical trial currently in the recruitment phase (Identifier number: NCT03826368) utilizing CBD as a dietary supplement to aid in recovery from brain injury in humans. Pharmacological treatment for concussion and post-concussion syndrome has been a persistent issue because of the complex nature of the injury, ${ }^{63}$ underreporting of the injury, ${ }^{200}$ and the absence of common physiological impairments or symptomology. ${ }^{3}$ The exact pathophysiology of concussion is still being researched, and as such there may be effects of CBD upon concussion which can potentially go unnoticed. Regardless, the presented research does provide a strong framework for future studies on the therapeutic evaluation of $\mathrm{CBD}$ on concussion.

\section{Conclusion}

This review presents research to suggest the potentially beneficial effects of CBD in treatment following mTBI such as concussion. CBD appears to regulate ionic balance, act as an anti-neuroinflammatory, attenuate dopaminergic pathway damage, and suppress the impairments of cerebral blood flow, heart rate variability, and the blood brain barrier. The general consensus for treatment following concussion is continuing to evolve, ${ }^{201}$ as the exact pathophysiology is not yet understood. Because there are many physiological consequences that arise due to head trauma, a single remedy to treat all impairments seems like a monumental task without assuming a polyprescription approach, which may result in a large amount of unwanted side effects. Although direct human research and double-blind randomized controlled trials are still lacking, there is much preclinical evidence and theoretical framework available to support the idea of using CBD following concussion due to its neuroprotective properties.

\section{ACKNOWLEDGEMENTS}

The authors would like to thank all those who contributed to the ideas presented in this review.

\section{Disclosures}

The authors report no conflicts of interest.

\section{Statement of Authorship}

JS and JPN conceived and revised this paper.

\section{REFERENCES}

1. Schurman LD, Lichtman AH. Endocannabinoids: a promising impact for traumatic brain injury. Front Pharmacol. 2017;8:69. doi: 10.3389/fphar.2017.00069.

2. Langlois JA, Rutland-Brown W, Wald MM. The epidemiology and impact of traumatic brain injury: a brief overview. J Head Trauma Rehabil. 2006;21(5):375-8.

3. McGeown JP, Hume PA, Kara S, Neary JP, Gardner W. Is it really the result of a concussion? Lessons from a case study. Sport Med Open. 2019;5(1):8. doi: 10.1186/s40798-019-0181-4.

4. Corrigan JD, Selassie AW, Orman JAL. The epidemiology of traumatic brain injury. J Head Trauma Rehabil. 2010;25(2):7280. doi: 10.1097/HTR.0b013e3181ccc8b4.

5. Bridgeman MB, Abazia DT. Medicinal cannabis: history, pharmacology, and implications for the acute care setting. P T. 2017; 42(3):180-88.

6. Shohami E, Cohen-Yeshurun A, Magid L, Algali M, Mechoulam R. Endocannabinoids and traumatic brain injury. Br J Pharmacol. 2011;163(7):1402-10. doi: 10.1111/j.1476-5381.2011.01343.x.

7. Atakan Z. Cannabis, a complex plant: different compounds and different effects on individuals. Ther Adv Psychopharmacol. 2012;2(6):241-54. doi: 10.1177/2045125312457586.

8. Hilderbrand RL. Hemp \& cannabidiol: what is a medicine? Mo Med. 2018;115(4):306-309. 
9. Maroon J, Bost J. Review of the neurological benefits of phytocannabinoids. Surg Neurol Int. 2018;9:91. doi: 10.4103/ sni.sni_45_18.

10. Li H, Kong W, Chambers $\mathrm{CR}$, et al. The non-psychoactive phytocannabinoid cannabidiol (CBD) attenuates pro-inflammatory mediators, $\mathrm{T}$ cell infiltration, and thermal sensitivity following spinal cord injury in mice. Cell Immunol. 2018;329:1-9. doi: 10.1016/j.cellimm.2018.02.016.

11. Russo EB. Taming THC: potential cannabis synergy and phytocannabinoid-terpenoid entourage effects. $\mathrm{Br} \mathrm{J}$ Pharmacol. 2011;163(7):1344-64. doi: 10.1111/j.1476-5381.2011.01238.x.

12. Sanchez-Ramos J. The entourage effect of the phytocannabinoids. Ann Neurol. 2015;77(6):1083. doi: 10.1002/ana.24402.

13. Russo EB. The case for the entourage effect and conventional breeding of clinical cannabis: no "strain," no gain. Front Plant Sci. 2018;9:1969. doi: 10.3389/fpls.2018.01969.

14. Zuardi AW, Crippa JAS, Hallak JEC, et al. A critical review of the antipsychotic effects of cannabidiol: 30 years of a translational investigation. Curr Pharm Des. 2012;18(32):5131-40.

15. Niesink RJM, Van Laar MW . Does cannabidiol protect against adverse psychological effects of THC? 2013;4:1-8. doi:10.3389/ fpsyt.2013.00130.

16. Klein C, Karanges E, Spiro A, et al. Cannabidiol potentiates Delta(9)-tetrahydrocannabinol (THC) behavioural effects and alters THC pharmacokinetics during acute and chronic treatment in adolescent rats. Psychopharmacology (Berl). 2011;218(2):44357. doi: 10.1007/s00213-011-2342-0.

17. Hlozek T, Uttl L, Kaderabek L, et al. Pharmacokinetic and behavioural profile of THC, CBD, and THC+CBD combination after pulmonary, oral, and subcutaneous administration in rats and confirmation of conversion in vivo of CBD to THC. Eur Neuropsychopharmacol. 2017;27(12):1223-37. doi: 10.1016/ j.euroneuro.2017.10.037.

18. Liu Z, Martin JH. Gaps in predicting clinical doses for cannabinoids therapy: overview of issues for pharmacokinetics and pharmacodynamics modelling. $\mathrm{Br} \mathrm{J}$ Clin Pharmacol. 2018;84(11):2483-87. doi: 10.1111/bcp.13635.

19. Millar SA, Stone NL, Yates AS, O'Sullivan SE. A systematic review on the pharmacokinetics of cannabidiol in humans. Front Pharmacol. 2018;9:1365. doi: 10.3389/fphar.2018.01365.

20. MacCallum CA, Russo EB. Practical considerations in medical cannabis administration and dosing. Eur J Intern Med. 2018:49:12-19. doi: 10.1016/j.ejim.2018.01.004.

21. Belardo C, Iannotta M, Boccella S, et al. Oral cannabidiol prevents allodynia and neurological dysfunctions in a mouse model of mild traumatic brain injury. Front Pharmacol. 2019;10:352. https:// www.frontiersin.org/article/10.3389/fphar.2019.00352.

22. Gaoni Y, Mechoulam R. Isolation structure and partial synthesis of an active constituent of hashish. J Am Chem Soc. 1964;86:1646-47.

23. Woodhams SG, Sagar DR, Burston JJ, Chapman V. The role of the endocannabinoid system in pain. Handb Exp Pharmacol. 2015;227:119-43. doi: 10.1007/978-3-662-46450-2 7.

24. Acharya N, Penukonda S, Shcheglova T, Hagymasi AT, Basu S, Srivastava PK. Endocannabinoid system acts as a regulator of immune homeostasis in the gut. Proc Natl Acad Sci U S A. 2017;114(19):5005-10. doi: 10.1073/pnas.1612177114.

25. Sierra S, Luquin N, Navarro-Otano J. The endocannabinoid system in cardiovascular function: novel insights and clinical implications. Clin Auton Res. 2018;28(1):35-52. doi: 10.1007/s10286017-0488-5.

26. Munro S, Thomas KL, Abu-Shaar M. Molecular characterization of a peripheral receptor for cannabinoids. Nature. 1993;365(6441): 61-65. doi: 10.1038/365061a0.

27. Devane WA, Dysarz FA 3rd, Johnson MR, Melvin LS, Howlett AC. Determination and characterization of a cannabinoid receptor in rat brain. Mol Pharmacol. 1988;34(5):605-13.

28. Dhopeshwarkar A, Mackie K. CB2 Cannabinoid receptors as a therapeutic target-what does the future hold? Mol Pharmacol. 2014;86(4):430-37. doi: 10.1124/mol.114.094649.

29. Hillard CJ. The endocannabinoid signaling system in the CNS: a primer. Int Rev Neurobiol. 2015;125:1-47. doi: 10.1016/ bs.irn.2015.10.001.
30. Mackie K. Mechanisms of CB1 receptor signaling: endocannabinoid modulation of synaptic strength. Int J Obes (Lond). 2006;30 (Suppl 1):S19-23. doi: 10.1038/sj.ijo.0803273.

31. Corcoran L, Roche M, Finn DP. The role of the brain's endocannabinoid system in pain and its modulation by stress. Int Rev Neurobiol. 2015;125:203-55. doi: 10.1016/bs.irn.2015.10.003.

32. Ryskamp DA, Redmon S, Jo AO, Križaj D. TRPV1 and endocannabinoids: emerging molecular signals that modulate mammalian vision. Cells. 2014;3(3):914-38. doi: 10.3390/cells3030914.

33. Olah A, Toth BI, Borbiro I, et al. Cannabidiol exerts sebostatic and antiinflammatory effects on human sebocytes. J Clin Invest. 2014;124(9):3713-24. doi: 10.1172/JCI64628.

34. Oláh A, Bíró T. Targeting cutaneous cannabinoid signaling in inflammation - a "high"-way to heal? EBioMedicine. 2017; 16:3-5. doi: 10.1016/j.ebiom.2017.01.003.

35. Russo EB, Burnett A, Hall B, Parker KK. Agonistic properties of cannabidiol at 5-HT1a receptors. Neurochem Res. 2005; 30(8):1037-43. doi: 10.1007/s11064-005-6978-1.

36. Resstel LBM, Tavares RF, Lisboa SFS, Joca SRL, Corrêa FMA, Guimarães FS. 5-HT1A receptors are involved in the cannabidiolinduced attenuation of behavioural and cardiovascular responses to acute restraint stress in rats. Br J Pharmacol. 2009;156(1): 181-88. doi: 10.1111/j.1476-5381.2008.00046.x.

37. Morales P, Reggio PH. An update on non-CB1, Non-CB2 cannabinoid related G-protein-coupled receptors. Cannabis Cannabinoid Res. 2017;2(1):265-73. doi: 10.1089/can.2017.0036.

38. Mackie K. Cannabinoid receptors: where they are and what they do. J Neuroendocrinol. 2008;20(Suppl 1):10-14. doi: 10.1111/ j.1365-2826.2008.01671.x.

39. Turcotte C, Blanchet M-R, Laviolette M, Flamand N. The CB(2) receptor and its role as a regulator of inflammation. Cell Mol Life Sci. 2016;73(23):4449-70. doi: 10.1007/s00018-016-2300-4.

40. Atwood BK, Mackie K. CB2: a cannabinoid receptor with an identity crisis. Br J Pharmacol. 2010;160(3):467-79. doi: 10.1111/j.1476-5381.2010.00729.x.

41. Pacher $P$, Mechoulam R. Is lipid signaling through cannabinoid 2 receptors part of a protective system? Prog Lipid Res. 2011; 50(2):193-211. doi: 10.1016/j.plipres.2011.01.001.

42. Cabral GA, Raborn ES, Griffin L, Dennis J, Marciano-Cabral F. $\mathrm{CB} 2$ receptors in the brain: role in central immune function. $\mathrm{Br} \mathrm{J}$ Pharmacol. 2008;153(2):240-51. doi: 10.1038/sj.bjp.0707584.

43. Schatz AR, Lee M, Condie RB, Pulaski JT, Kaminski NE. Cannabinoid receptors $\mathrm{CB} 1$ and $\mathrm{CB} 2$ : a characterization of expression and adenylate cyclase modulation within the immune system. Toxicol Appl Pharmacol. 1997;142(2):278-87. doi: 10.1006/taap.1996.8034.

44. Galiegue S, Mary S, Marchand J, et al. Expression of central and peripheral cannabinoid receptors in human immune tissues and leukocyte subpopulations. Eur J Biochem. 1995;232(1):54-61. doi: 10.1111/j.1432-1033.1995.tb20780.x.

45. Kendall DA, Yudowski GA. Cannabinoid receptors in the central nervous system: their signaling and roles in disease. Front Cell Neurosci. 2016;10:294. doi: 10.3389/fncel.2016.00294.

46. Dheen ST, Kaur C, Ling E-A. Microglial activation and its implications in the brain diseases. Curr Med Chem. 2007;14(11):1189-97.

47. Li A-L, Carey LM, Mackie K, Hohmann AG. Cannabinoid CB(2) agonist GW405833 suppresses inflammatory and neuropathic pain through a $\mathrm{CB}(1)$ mechanism that is independent of $\mathrm{CB}(2)$ receptors in mice. J Pharmacol Exp Ther. 2017;362(2):296-305. doi: 10.1124/jpet.117.241901.

48. Teixeira-Clerc F, Belot M-P, Manin S, et al. Beneficial paracrine effects of cannabinoid receptor 2 on liver injury and regeneration. Hepatology. 2010;52(3):1046-59. doi: 10.1002/hep.23779.

49. Baty DE, Zhang M, Li H, et al. Cannabinoid CB2 receptor activation attenuates motor and autonomic function deficits in a mouse model of spinal cord injury. Clin Neurosurg. 2008;55:172-77.

50. Spiro AS, Wong A, Boucher AA, Arnold JC. Enhanced brain disposition and effects of Delta9-tetrahydrocannabinol in P-glycoprotein and breast cancer resistance protein knockout mice. PLoS One. 2012;7(4):e35937. doi: 10.1371/journal.pone.0035937.

51. Holland ML, Panetta JA, Hoskins JM, et al. The effects of cannabinoids on P-glycoprotein transport and expression in 
multidrug resistant cells. Biochem Pharmacol. 2006;71(8):114654. doi: 10.1016/j.bcp.2005.12.033.

52. Britch SC, Wiley JL, Yu Z, Clowers BH, Craft RM. Cannabidiol$\Delta$ (9)-tetrahydrocannabinol interactions on acute pain and locomotor activity. Drug Alcohol Depend. 2017;175:187-97. doi: 10.1016/j.drugalcdep.2017.01.046.

53. Yang L, Li F-F, Han Y-C, Jia B, Ding Y. Cannabinoid receptor $\mathrm{CB} 2$ is involved in tetrahydrocannabinol-induced anti-inflammation against lipopolysaccharide in MG-63 cells. Mediators Inflamm. 2015;2015:362126. doi: 10.1155/2015/362126.

54. Bloomfield MAP, Ashok AH, Volkow ND, Howes OD. The effects of $\Delta(9)$-tetrahydrocannabinol on the dopamine system. Nature. 2016;539(7629):369-77. doi: 10.1038/nature20153.

55. Chen Y-H, Huang EY-K, Kuo T-T, Miller J, Chiang Y-H, Hoffer BJ. Impact of traumatic brain injury on dopaminergic transmission. Cell Transplant. 2017;26(7):1156-68. doi: 10.1177/ 0963689717714105.

56. Daneshvar DH, Nowinski CJ, McKee AC, Cantu RC. The epidemiology of sport-related concussion. Clin Sports Med. 2011;30(1):1-17, vii. doi: 10.1016/j.csm.2010.08.006.

57. Tsushima WT, Siu AM, Ahn HJ, Chang BL, Murata NM. Incidence and risk of concussions in youth athletes: comparisons of age, sex, concussion history, sport, and football position. Arch Clin Neuropsychol Off J Natl Acad Neuropsychol. 2019;34(1):60-69. doi: 10.1093/arclin/acy019.

58. Chrisman SPD, Lowry S, Herring SA, et al. Concussion incidence, duration, and return to school and sport in 5- to 14-year-old American football athletes. J Pediatr. 2019;207:176-84.e1. doi: 10.1016/j.jpeds.2018.11.003.

59. Halstead ME, Walter KD. Sport-related concussion in children and adolescents. Pediatrics. 2010;126(3):597-615. doi: 10.1542/ peds.2010-2005.

60. Voormolen DC, Polinder S, von Steinbuechel N, Vos PE, Cnossen MC, Haagsma JA. The association between post-concussion symptoms and health-related quality of life in patients with mild traumatic brain injury. Injury. 2019;50(5):1068-74. doi: 10.1016/ j.injury.2018.12.002.

61. Polinder S, Cnossen MC, Real RGL, et al. A Multidimensional approach to post-concussion symptoms in mild traumatic brain injury. Front Neurol. 2018;9:1113. doi: 10.3389/fneur.2018.01113.

62. Theadom A, Parag V, Dowell T, et al. Persistent problems 1 year after mild traumatic brain injury: a longitudinal population study in New Zealand. Br J Gen Pract. 2016;66(642):e16-23. doi: 10.3399/bjgp16X683161.

63. Giza CC, Hovda DA. The new neurometabolic cascade of concussion. Neurosurgery. 2014;75(Suppl 4):S24-33. doi: 10.1227/ NEU.0000000000000505.

64. Len TK, Neary JP, Asmundson GJG, Goodman DG, Bjornson B, Bhambhani YN. Cerebrovascular reactivity impairment after sportinduced concussion. Med Sci Sports Exerc. 2011;43(12):2241-48. doi: 10.1249/MSS.0b013e3182249539.

65. Buki A, Povlishock JT. All roads lead to disconnection? - Traumatic axonal injury revisited. Acta Neurochir (Wien). 2006;148(2): 181-84. doi: 10.1007/s00701-005-0674-4.

66. Bishop S, Dech R, Baker T, Butz M, Aravinthan K, Neary JP. Parasympathetic baroreflexes and heart rate variability during acute stage of sport concussion recovery. Brain Inj. 2017;31(2):247-59. doi: 10.1080/02699052.2016.1226385.

67. Neary JP, Singh J, Bishop SA, Dech RT, Butz MJA, Len TK. An evidence-based objective study protocol for evaluating cardiovascular and cerebrovascular indices following concussion: the Neary protocol. Methods Protoc. 2019;2(1):23. doi: 10.3390/ mps2010023.

68. Study AFNS, Hocke LM, Duszynski CC, Debert CT, Dleikan D, Dunn JF. Reduced functional connectivity in adults with persistent post-concussion symptoms. 2018;9:1-9. doi:10.1089/ neu.2017.5365.

69. Choe MC. The pathophysiology of concussion. Curr Pain Headache Rep. 2016;20(6):42. doi: 10.1007/s11916-016-0573-9.

70. Cheng G, Kong R, Zhang L, Zhang J. Mitochondria in traumatic brain injury and mitochondrial-targeted multipotential therapeutic strategies. Br J Pharmacol. 2012;167(4):699-719. doi: 10.1111/ j.1476-5381.2012.02025.x.
71. Johnson VE, Weber MT, Xiao R, et al. Mechanical disruption of the blood-brain barrier following experimental concussion. Acta Neuropathol. 2018;135(5):711-26. doi: 10.1007/s00401-0181824-0.

72. Shetty AK, Mishra V, Kodali M, Hattiangady B. Blood brain barrier dysfunction and delayed neurological deficits in mild traumatic brain injury induced by blast shock waves. Front Cell Neurosci. 2014;8:232. doi: 10.3389/fncel.2014.00232.

73. Len TK, Neary JP, Asmundson GJG, et al. Serial monitoring of $\mathrm{CO} 2$ reactivity following sport concussion using hypocapnia and hypercapnia. Brain Inj. 2013;27(3):346-53. doi: 10.3109/ 02699052.2012 .743185$.

74. Bishop SA, Dech RT, Guzik P, Neary JP. Heart rate variability and implication for sport concussion. Clin Physiol Funct Imaging. 2017;38(5):733-42. doi: 10.1111/cpf.12487.

75. La Fountaine MF, Hohn AN, Testa AJ, Weir JP. Attenuation of spontaneous baroreceptor sensitivity following concussion. Med Sci Sports Exerc. 2018. doi: 10.1249/MSS.00000000000 01833.

76. Jang H, Huang S, Hammer DX, et al. Alterations in neurovascular coupling following acute traumatic brain injury. Neurophotonics. 2017;4(4):45007. doi: 10.1117/1.NPh.4.4.045007.

77. Barth JT, Freeman JR, Broshek DK, Varney RN. Accelerationdeceleration sport-related concussion: the gravity of it all. J Athl Train. 2001;36(3):253-56.

78. Ivancevic VG. New mechanics of traumatic brain injury. Cogn Neurodyn. 2009;3(3):281-93. doi: 10.1007/s11571-008-9070-0.

79. $\mathrm{Xu} \mathrm{J}-\mathrm{Y}$, Chen $\mathrm{C}$. Endocannabinoids in synaptic plasticity and neuroprotection. Neurosci a Rev J bringing Neurobiol Neurol Psychiatry. 2015;21(2):152-68. doi: 10.1177/1073858414524632.

80. Mechoulam R, Spatz M, Shohami E. Endocannabinoids and neuroprotection. Sci STKE. 2002;2002(129):re5. doi: 10.1126/ stke.2002.129.re5.

81. Diana MA, Marty A. Endocannabinoid-mediated short-term synaptic plasticity: depolarization-induced suppression of inhibition (DSI) and depolarization-induced suppression of excitation (DSE). Br J Pharmacol. 2004;142(1):9-19. doi: 10.1038/sj.bjp. 0705726.

82. Barrie N, Manolios N. The endocannabinoid system in pain and inflammation: its relevance to rheumatic disease. Eur J Rheumatol. 2017;4(3):210-18. doi: 10.5152/eurjrheum.2017.17025.

83. Prescott SM, Majerus PW. Characterization of 1,2-diacylglycerol hydrolysis in human platelets. Demonstration of an arachidonoylmonoacylglycerol intermediate. J Biol Chem. 1983;258(2): 764-69.

84. Sugiura T, Kondo S, Sukagawa A, et al. 2-Arachidonoylglycerol: a possible endogenous cannabinoid receptor ligand in brain. Biochem Biophys Res Commun. 1995;215(1):89-97. doi: 10.1006/ bbrc.1995.2437.

85. Di Marzo V. Endocannabinoids: synthesis and degradation. Rev Physiol Biochem Pharmacol. 2008;160:1-24. doi: 10.1007/ $112 \_0505$.

86. Placzek EA, Okamoto Y, Ueda N, Barker EL. Mechanisms for recycling and biosynthesis of endogenous cannabinoids anandamide and 2-arachidonylglycerol. J Neurochem. 2008;107(4): 987-1000. doi: 10.1111/j.1471-4159.2008.05659.x.

87. Giuffrida A, Beltramo M, Piomelli D. Mechanisms of endocannabinoid inactivation: biochemistry and pharmacology. J Pharmacol Exp Ther. 2001;298(1):7-14.

88. Grotenhermen F. Pharmacokinetics and pharmacodynamics of cannabinoids. Clin Pharmacokinet. 2003;42(4):327-360. doi: 10.2165/00003088-200342040-00003.

89. Grotenhermen F. Clinical pharmacodynamics of cannabinoids. J Cannabis Ther. 2004;4(1):29-78. doi: 10.1300/J175v04n01_03.

90. Pope C, Mechoulam R, Parsons L. Endocannabinoid signaling in neurotoxicity and neuroprotection. Neurotoxicology. 2010; 31(5):562-71. doi: 10.1016/j.neuro.2009.12.002.

91. Deutsch DG, Chin SA. Enzymatic synthesis and degradation of anandamide, a cannabinoid receptor agonist. Biochem Pharmacol. 1993;46(5):791-96.

92. Mechoulam R, Peters M, Murillo-Rodriguez E, Hanus LO. Cannabidiol - recent advances. Chem Biodivers. 2007;4(8):1678-92. doi: $10.1002 / \mathrm{cbdv} .200790147$. 
93. Iffland K, Grotenhermen F. An update on safety and side effects of cannabidiol : a review of clinical data and relevant animal Studies. 2017;2:139-54. doi: 10.1089/can.2016.0034.

94. Costa B, Giagnoni G, Franke C, Trovato AE, Colleoni M. Vanilloid TRPV1 receptor mediates the antihyperalgesic effect of the nonpsychoactive cannabinoid, cannabidiol, in a rat model of acute inflammation. $\mathrm{Br}$ J Pharmacol. 2004;143(2):247-50. doi: 10.1038/sj.bjp.0705920.

95. Pazos MR, Mohammed N, Lafuente H, et al. Mechanisms of cannabidiol neuroprotection in hypoxic-ischemic newborn pigs: role of 5HT(1A) and CB2 receptors. Neuropharmacology. 2013;71:282-91. doi: 10.1016/j.neuropharm.2013.03.027.

96. Mishima K, Hayakawa K, Abe K, et al. Cannabidiol prevents cerebral infarction via a serotonergic 5-hydroxytryptamine1A receptor-dependent mechanism. Stroke. 2005;36(5):1077-82. doi: 10.1161/01.STR.0000163083.59201.34.

97. Hind WH, England TJ, O'Sullivan SE. Cannabidiol protects an in vitro model of the blood-brain barrier from oxygen-glucose deprivation via PPAR $\gamma$ and 5-HT1A receptors. Br J Pharmacol. 2016;173(5):815-25. doi: 10.1111/bph.13368.

98. Esposito G, Scuderi C, Valenza M, et al. Cannabidiol reduces Abeta-induced neuroinflammation and promotes hippocampal neurogenesis through PPARgamma involvement. PLoS One. 2011;6(12):e28668. doi: 10.1371/journal.pone.0028668.

99. Mecha M, Feliu A, Inigo PM, Mestre L, Carrillo-Salinas FJ, Guaza C. Cannabidiol provides long-lasting protection against the deleterious effects of inflammation in a viral model of multiple sclerosis: a role for A2A receptors. Neurobiol Dis. 2013;59: 141-50. doi: 10.1016/j.nbd.2013.06.016.

100. Castillo A, Tolon MR, Fernandez-Ruiz J, Romero J, MartinezOrgado J. The neuroprotective effect of cannabidiol in an in vitro model of newborn hypoxic-ischemic brain damage in mice is mediated by $\mathrm{CB}(2)$ and adenosine receptors. Neurobiol Dis. 2010;37(2):434-40. doi: 10.1016/j.nbd.2009.10.023.

101. Bisogno T, Hanus L, De Petrocellis L, et al. Molecular targets for cannabidiol and its synthetic analogues: effect on vanilloid VR1 receptors and on the cellular uptake and enzymatic hydrolysis of anandamide. Br J Pharmacol. 2001;134(4):845-52. doi: 10.1038/ sj.bjp.0704327.

102. Veldhuis WB, van der Stelt M, Wadman MW, et al. Neuroprotection by the endogenous cannabinoid anandamide and arvanil against in vivo excitotoxicity in the rat: role of vanilloid receptors and lipoxygenases. J Neurosci. 2003;23(10):4127-33.

103. Correa FG, Mestre L, Docagne F, Borrell J, Guaza C. The endocannabinoid anandamide from immunomodulation to neuroprotection. Implications for multiple sclerosis. Vitam Horm. 2009;81:207-30. doi: 10.1016/S0083-6729(09)81009-1.

104. Malek N, Popiolek-Barczyk K, Mika J, Przewlocka B, Starowicz K. Anandamide, acting via CB2 receptors, alleviates LPS-induced neuroinflammation in rat primary microglial cultures. Neural Plast. 2015;2015:130639. doi: 10.1155/2015/130639.

105. Caterina MJ, Leffler A, Malmberg AB, et al. Impaired nociception and pain sensation in mice lacking the capsaicin receptor. Science. 2000;288(5464):306-13.

106. Benyó Z, Ruisanchez É, Leszl-Ishiguro M, Sándor P, Pacher P. Endocannabinoids in cerebrovascular regulation. Am J Physiol Heart Circ Physiol. 2016;310(7):H785-801. doi: 10.1152/ ajpheart.00571.2015.

107. Len TK, Neary JP. Cerebrovascular pathophysiology following mild traumatic brain injury. Clin Physiol Funct Imaging. 2011;31(2):85-93. doi: 10.1111/j.1475-097X.2010.00990.x.

108. Bishop SA, Neary JP. Assessing prefrontal cortex oxygenation after sport concussion with near-infrared spectroscopy. Clin Physiol Funct Imaging. 2017;38(4):573-85. doi: 10.1111/ cpf.12447.

109. Aso E, Fernandez-Duenas V, Lopez-Cano M, et al. Adenosine A2A-cannabinoid CB1 receptor heteromers in the hippocampus: cannabidiol blunts Delta(9)-tetrahydrocannabinol-induced cognitive impairment. Mol Neurobiol. 2019. doi: 10.1007/s12035-0181456-3.

110. Garcia-Garcia AL, Meng Q, Canetta S, et al. Serotonin signaling through prefrontal cortex 5-HT(1A) receptors during adolescence can determine baseline mood-related behaviors. Cell Rep. 2017;18(5):1144-56. doi: 10.1016/j.celrep.2017.01.021.

111. Pompeiano M, Palacios JM, Mengod G. Distribution and cellular localization of mRNA coding for 5-HT1A receptor in the rat brain: correlation with receptor binding. J Neurosci. 1992;12(2):440-53.

112. Linge R, Jimenez-Sanchez L, Campa L, et al. Cannabidiol induces rapid-acting antidepressant-like effects and enhances cortical 5-HT/glutamate neurotransmission: role of 5-HT1A receptors. Neuropharmacology. 2016;103:16-26. doi: 10.1016/ j.neuropharm.2015.12.017.

113. O'Sullivan SE. An update on PPAR activation by cannabinoids. Br J Pharmacol. 2016;173(12):1899-910. doi: 10.1111/bph. 13497.

114. Tyagi S, Gupta P, Saini AS, Kaushal C, Sharma S. The peroxisome proliferator-activated receptor: a family of nuclear receptors role in various diseases. J Adv Pharm Technol Res. 2011;2(4):236-40. doi: 10.4103/2231-4040.90879.

115. Scuderi C, Steardo L, Esposito G. Cannabidiol promotes amyloid precursor protein ubiquitination and reduction of beta amyloid expression in SHSY5YAPP+ cells through PPARgamma involvement. Phytother Res. 2014;28(7):1007-13. doi: 10.1002/ ptr.5095.

116. Ramer R, Heinemann K, Merkord J, et al. COX-2 and PPARgamma confer cannabidiol-induced apoptosis of human lung cancer cells. Mol Cancer Ther. 2013;12(1):69-82. doi: 10.1158/ 1535-7163.MCT-12-0335.

117. Wang D, Shi L, Xin W, et al. Activation of PPARgamma inhibits pro-inflammatory cytokines production by upregulation of miR124 in vitro and in vivo. Biochem Biophys Res Commun. 2017;486(3):726-31. doi: 10.1016/j.bbrc.2017.03.106.

118. Console-Bram L, Brailoiu E, Brailoiu GC, Sharir H, Abood ME. Activation of GPR18 by cannabinoid compounds: a tale of biased agonism. Br J Pharmacol. 2014;171(16):3908-17. doi: 10.1111/ bph.12746.

119. Penumarti A, Abdel-Rahman AA. The novel endocannabinoid receptor GPR18 is expressed in the rostral ventrolateral medulla and exerts tonic restraining influence on blood pressure. J Pharmacol Exp Ther. 2014;349(1):29-38. doi: 10.1124/jpet.113.209213.

120. Begg M, Pacher P, Batkai S, et al. Evidence for novel cannabinoid receptors. Pharmacol Ther. 2005;106(2):133-45. doi: 10.1016/ j.pharmthera.2004.11.005.

121. Patterson ZR, Holahan MR. Understanding the neuroinflammatory response following concussion to develop treatment strategies. Front Cell Neurosci. 2012;6:58. doi: 10.3389/ fncel.2012.00058.

122. Kawamata T, Katayama Y, Hovda DA, Yoshino A, Becker DP. Lactate accumulation following concussive brain injury: the role of ionic fluxes induced by excitatory amino acids. Brain Res. 1995;674(2):196-204.

123. Kim S, Han SC, Gallan AJ, Hayes JP. Neurometabolic indicators of mitochondrial dysfunction in repetitive mild traumatic brain injury. Concussion. 2017;2(3):CNC45. doi: 10.2217/cnc2017-0013.

124. Ryan D, Drysdale AJ, Lafourcade C, Pertwee RG, Platt B. Cannabidiol targets mitochondria to regulate intracellular $\mathrm{Ca} 2+$ levels. J Neurosci. 2009;29(7):2053-63. doi: 10.1523/JNEUROSCI.4212-08.2009.

125. Mori MA, Meyer E, Soares LM, Milani H, Guimaraes FS, de Oliveira RMW. Cannabidiol reduces neuroinflammation and promotes neuroplasticity and functional recovery after brain ischemia. Prog Neuropsychopharmacol Biol Psychiatry. 2017;75:94-105. doi: 10.1016/j.pnpbp.2016.11.005.

126. Hayakawa K, Mishima K, Nozako M, et al. Delayed treatment with cannabidiol has a cerebroprotective action via a cannabinoid receptor-independent myeloperoxidase-inhibiting mechanism. J Neurochem. 2007;102(5):1488-96. doi: 10.1111/j.14714159.2007.04565.x.

127. Lafuente H, Alvarez FJ, Pazos MR, et al. Cannabidiol reduces brain damage and improves functional recovery after acute hypoxia-ischemia in newborn pigs. Pediatr Res. 2011;70(3): 272-77. doi: 10.1203/PDR.0b013e3182276b11. 
128. Sahyouni R, Gutierrez P, Gold E, Robertson RT, Cummings BJ. Effects of concussion on the blood-brain barrier in humans and rodents. J Concussion. 2017;1:205970021668451. doi: 10.1177/ 2059700216684518.

129. Gallily R, Breuer A, Mechoulam R. 2-Arachidonylglycerol, an endogenous cannabinoid, inhibits tumor necrosis factor-alpha production in murine macrophages, and in mice. Eur J Pharmacol. 2000;406(1):R5-7.

130. Juttler E, Potrovita I, Tarabin V, et al. The cannabinoid dexanabinol is an inhibitor of the nuclear factor-kappa B (NF-kappa B). Neuropharmacology. 2004;47(4):580-92. doi: 10.1016/ j.neuropharm.2004.05.009.

131. Varatharaj A, Galea I. The blood-brain barrier in systemic inflammation. Brain Behav Immun. 2017;60:1-12. doi: 10.1016/ j.bbi.2016.03.010.

132. Shohami E, Beit-Yannai E, Horowitz M, Kohen R. Oxidative stress in closed-head injury: brain antioxidant capacity as an indicator of functional outcome. J Cereb Blood Flow Metab. 1997;17(10):1007-19. doi: 10.1097/00004647-19971000000002 .

133. Panikashvili D, Simeonidou C, Ben-Shabat S, et al. An endogenous cannabinoid (2-AG) is neuroprotective after brain injury. Nature. 2001;413(6855):527-31. doi: 10.1038/35097089.

134. Mechoulam R, Shohami E. Endocannabinoids and traumatic brain injury. Mol Neurobiol. 2007;36(1):68-74. doi: 10.1007/s12035007-8008-6.

135. Vendel E, de Lange ECM. Functions of the CB1 and CB2 receptors in neuroprotection at the level of the blood-brain barrier. Neuromolecular Med. 2014;16(3):620-42. doi: 10.1007/s12017014-8314-x.

136. Di Marzo V, De Petrocellis L. Why do cannabinoid receptors have more than one endogenous ligand? Philos Trans R Soc London Ser B Biol Sci. 2012;367(1607):3216-28. doi: 10.1098/rstb. 2011.0382 .

137. Sugiura T, Kishimoto S, Oka S, Gokoh M. Biochemistry, pharmacology and physiology of 2-arachidonoylglycerol, an endogenous cannabinoid receptor ligand. Prog Lipid Res. 2006;45(5):405-46. https://doi.org/10.1016/j.plipres.2006.03.003.

138. Brook E, Mamo J, Wong R, et al. Blood-brain barrier disturbances in diabetes-associated dementia: therapeutic potential for cannabinoids. Pharmacol Res. 2019;141:291-97. https://doi.org/ 10.1016/j.phrs.2019.01.009.

139. Cassol OJJ, Comim CM, Silva BR, et al. Treatment with cannabidiol reverses oxidative stress parameters, cognitive impairment and mortality in rats submitted to sepsis by cecal ligation and puncture. Brain Res. 2010;1348:128-38. doi: 10.1016/j.brainres. 2010.06.023.

140. Mecha M, Torrao AS, Mestre L, Carrillo-Salinas FJ, Mechoulam $\mathrm{R}$, Guaza C. Cannabidiol protects oligodendrocyte progenitor cells from inflammation-induced apoptosis by attenuating endoplasmic reticulum stress. Cell Death Dis. 2012;3:e331. doi: 10.1038/cddis.2012.71.

141. Rajesh M, Mukhopadhyay P, Batkai S, et al. Cannabidiol attenuates cardiac dysfunction, oxidative stress, fibrosis, and inflammatory and cell death signaling pathways in diabetic cardiomyopathy. J Am Coll Cardiol. 2010;56(25):2115-25. doi: $10.1016 /$ j.jacc.2010.07.033.

142. Saito VM, Rezende RM, Teixeira AL. Cannabinoid modulation of neuroinflammatory disorders. Curr Neuropharmacol. 2012;10(2):159-66. doi: 10.2174/157015912800604515.

143. Kontos HA, Povlishock JT. Oxygen radicals in brain injury. Cent Nerv Syst Trauma. 1986;3(4):257-63.

144. Povlishock JT, Kontos HA. The role of oxygen radicals in the pathobiology of traumatic brain injury. Hum Cell. 1992;5(4): 345-53.

145. Borges RS, Batista JJ, Viana RB, et al. Understanding the molecular aspects of tetrahydrocannabinol and cannabidiol as antioxidants. Molecules. 2013;18(10):12663-674. doi: 10.3390/ molecules 181012663.

146. Hampson AJ, Grimaldi M, Axelrod J, Wink D. Cannabidiol and (-) Delta9-tetrahydrocannabinol are neuroprotective antioxidants. Proc Natl Acad Sci U S A. 1998;95(14):8268-73.
147. Atalay S, Jarocka-Karpowicz I, Skrzydlewska E. Antioxidative and anti-inflammatory properties of cannabidiol. Antioxidants (Basel, Switzerland). 2019;9(1). doi: 10.3390/antiox9010021.

148. El-Remessy AB, Khalil IE, Matragoon S, et al. Neuroprotective effect of (-)Delta9-tetrahydrocannabinol and cannabidiol in $\mathrm{N}$-methyl-D-aspartate-induced retinal neurotoxicity: involvement of peroxynitrite. Am J Pathol. 2003;163(5):1997-2008.

149. Binder DK, Scharfman HE. Brain-derived neurotrophic factor. Growth Factors. 2004;22(3):123-31. doi: 10.1080/0897719041 0001723308.

150. Lohof AM, Ip NY, Poo MM. Potentiation of developing neuromuscular synapses by the neurotrophins NT-3 and BDNF. Nature. 1993;363(6427):350-53. doi: 10.1038/363350a0.

151. Magen I, Avraham Y, Ackerman Z, Vorobiev L, Mechoulam R, Berry EM. Cannabidiol ameliorates cognitive and motor impairments in bile-duct ligated mice via 5-HT1A receptor activation. Br J Pharmacol. 2010;159(4):950-57. doi: 10.1111/j.14765381.2009.00589.x.

152. Fuller JJL, Murray RC, Horner KA. D-Amphetamine withdrawalinduced decreases in brain-derived neurotrophic factor in sprague-dawley rats are reversed by treatment with ketamine. Neuropharmacology. 2015;97:7-17. doi: 10.1016/j.neuropharm. 2015.04.023.

153. Campos AC, Fogaça M V, Sonego AB, Guimarães FS. Cannabidiol, neuroprotection and neuropsychiatric disorders. Pharmacol Res. 2016;112:119-27. doi: https://doi.org/10.1016/j.phrs.2016.01.033.

154. Valvassori SS, Elias G, de Souza B, et al. Effects of cannabidiol on amphetamine-induced oxidative stress generation in an animal model of mania. J Psychopharmacol. 2011;25(2):274-80. doi: 10.1177/0269881109106925.

155. Campos AC, Brant F, Miranda AS, Machado FS, Teixeira AL. Cannabidiol increases survival and promotes rescue of cognitive function in a murine model of cerebral malaria. Neuroscience. 2015; 289:166-80. https://doi.org/10.1016/j.neuroscience.2014.12.051.

156. Sales AJ, Fogaca M V, Sartim AG, et al. Cannabidiol induces rapid and sustained antidepressant-like effects through increased BDNF signaling and synaptogenesis in the prefrontal cortex. Mol Neurobiol. 2019;56(2):1070-81. doi: 10.1007/s12035-018-1143-4.

157. Korley FK, Diaz-Arrastia R, Wu AHB, et al. Circulating brainderived neurotrophic factor has diagnostic and prognostic value in traumatic brain injury. J Neurotrauma. 2016;33(2):215-25. doi: 10.1089/neu.2015.3949.

158. Giza CC, Difiori JP. Pathophysiology of sports-related concussion: an update on basic science and translational research. Sports Health. 2011;3(1):46-51. doi: 10.1177/1941738110391732.

159. Siuda J, Patalong-Ogiewa M, Zmuda W, et al. Cognitive impairment and BDNF serum levels. Neurol Neurochir Pol. 2017;51(1):24-32. doi: 10.1016/j.pjnns.2016.10.001.

160. Logothetis NK. What we can do and what we cannot do with fMRI. Nature. 2008;453(7197):869-78. doi: 10.1038/nature06976.

161. Winton-Brown TT, Allen P, Bhattacharyya S, et al. Modulation of auditory and visual processing by Delta-9-tetrahydrocannabinol and cannabidiol: an FMRI study. Neuropsychopharmacology. 2011;36(7):1340-48. doi: 10.1038/npp.2011.17.

162. Bhattacharyya S, Morrison PD, Fusar-Poli P, et al. Opposite effects of Delta-9-tetrahydrocannabinol and cannabidiol on human brain function and psychopathology. Neuropsychopharmacology. 2010;35(3):764-74. doi: 10.1038/npp.2009.184.

163. Colizzi M, Bhattacharyya S. Does cannabis composition matter? differential effects of Delta-9-tetrahydrocannabinol and cannabidiol on human cognition. Curr Addict reports. 2017;4(2):62-74. doi: 10.1007/s40429-017-0142-2.

164. Morgan CJA, Schafer G, Freeman TP, Curran HV. Impact of cannabidiol on the acute memory and psychotomimetic effects of smoked cannabis: naturalistic study: naturalistic study [corrected]. Br J Psychiatry. 2010;197(4):285-90. doi: 10.1192/ bjp.bp.110.077503.

165. Hindocha C, Freeman TP, Schafer G, et al. Acute effects of Delta-9tetrahydrocannabinol, cannabidiol and their combination on facial emotion recognition: a randomised, double-blind, placebocontrolled study in cannabis users. Eur Neuropsychopharmacol. 2015;25(3):325-34. doi: 10.1016/j.euroneuro.2014.11.014. 
166. Englund A, Morrison PD, Nottage J, et al. Cannabidiol inhibits THC-elicited paranoid symptoms and hippocampal-dependent memory impairment. J Psychopharmacol. 2013;27(1):19-27. doi: $10.1177 / 0269881112460109$.

167. Morgan CJA, Gardener C, Schafer G, et al. Sub-chronic impact of cannabinoids in street cannabis on cognition, psychotic-like symptoms and psychological well-being. Psychol Med. 2012;42(2):391-400. doi: 10.1017/S0033291711001322.

168. Bahr BA, Karanian DA, Makanji SS, Makriyannis A. Targeting the endocannabinoid system in treating brain disorders. Expert Opin Investig Drugs. 2006;15(4):351-65. doi: 10.1517/13543784.15. 4.351 .

169. Hayakawa K, Mishima K, Fujiwara M. Therapeutic potential of non-psychotropic cannabidiol in ischemic stroke. Pharmaceuticals (Basel). 2010;3(7):2197-12. doi: 10.3390/ph3072197.

170. Richter JS, Quenardelle V, Rouyer O, et al. A systematic review of the complex effects of cannabinoids on cerebral and peripheral circulation in animal models. Front Physiol. 2018;9:622. doi: 10.3389/fphys.2018.00622.

171. Tan CO, Meehan WP 3rd, Iverson GL, Taylor JA. Cerebrovascular regulation, exercise, and mild traumatic brain injury. Neurology. 2014;83(18):1665-72. doi: 10.1212/WNL.0000 000000000944

172. Crippa JAdS, Zuardi AW, Garrido GEJ, et al. Effects of cannabidiol (CBD) on regional cerebral blood flow. Neuropsychopharmacology. 2004;29(2):417-26. doi: 10.1038/sj.npp.1300340.

173. Ruiz-Valdepeñas L, Martínez-Orgado JA, Benito C, Millán Á, Tolón RM, Romero J. Cannabidiol reduces lipopolysaccharideinduced vascular changes and inflammation in the mouse brain: an intravital microscopy study. J Neuroinflammation. 2011;8(1):5. doi: 10.1186/1742-2094-8-5.

174. Leweke FM, Piomelli D, Pahlisch F, et al. Cannabidiol enhances anandamide signaling and alleviates psychotic symptoms of schizophrenia. Transl Psychiatry. 2012;2(3):e94. doi: 10.1038/ tp.2012.15.

175. Hocke LM, Duszynski CC, Debert CT, Dleikan D, Dunn JF. Reduced functional connectivity in adults with persistent postconcussion symptoms: a functional near-infrared spectroscopy study. J Neurotrauma. 2018;35(11):1224-32. doi: 10.1089/ neu.2017.5365.

176. Johnson B, Zhang K, Gay M, et al. Alteration of brain default network in subacute phase of injury in concussed individuals: resting-state fMRI study. Neuroimage. 2012;59(1):511-18. doi: 10.1016/j.neuroimage.2011.07.081.

177. Mayer AR, Mannell MV, Ling J, Gasparovic C, Yeo RA. Functional connectivity in mild traumatic brain injury. Hum Brain Mapp. 2011;32(11):1825-35. doi: 10.1002/hbm.21151.

178. Raichle ME. The brain's default mode network. Annu Rev Neurosci. 2015;38(1):433-47. doi: 10.1146/annurev-neuro-071013-014030.

179. Wall MB, Pope R, Freeman TP, et al. Dissociable effects of cannabis with and without cannabidiol on the human brain's resting-state functional connectivity. J Psychopharmacol. 2019;33(7):822-30. doi: 10.1177/0269881119841568.

180. Pretzsch CM, Voinescu B, Mendez MA, et al. The effect of cannabidiol (CBD) on low-frequency activity and functional connectivity in the brain of adults with and without autism spectrum disorder (ASD). J Psychopharmacol. 2019:269881119858306. doi: 10.1177/0269881119858306.

181. Palmer AM, Marion DW, Botscheller ML, Swedlow PE, Styren SD, DeKosky ST. Traumatic brain injury-induced excitotoxicity assessed in a controlled cortical impact model. J Neurochem. 1993;61(6):2015-24. doi: 10.1111/j.1471-4159.1993.tb07437.x.

182. Sauerbeck A, Hunter R, Bing G, Sullivan PG. Traumatic brain injury and trichloroethylene exposure interact and produce functional, histological, and mitochondrial deficits. Exp Neurol. 2012;234(1):85-94. doi: 10.1016/j.expneurol.2011.12.012.

183. Seeman P. Cannabidiol is a partial agonist at dopamine D2High receptors, predicting its antipsychotic clinical dose. Transl Psychiatry. 2016;6(10):e920. doi: 10.1038/tp.2016.195.

184. Garcia C, Palomo-Garo C, Garcia-Arencibia M, Ramos J, Pertwee R, Fernandez-Ruiz J. Symptom-relieving and neuroprotective effects of the phytocannabinoid Delta(9)-THCV in animal models of Parkinson's disease. Br J Pharmacol. 2011;163(7):1495-506. doi: 10.1111/j.1476-5381.2011.01278.x

185. Peres FF, Lima AC, Hallak JEC, Crippa JA, Silva RH, Abílio VC. Cannabidiol as a promising strategy to treat and prevent movement disorders? Front Pharmacol. 2018;9:482. doi: 10.3389/ fphar.2018.00482.

186. Vinik AI, Dan Z. Diabetic cardiovascular autonomic neuropathy. Circulation. 2007;115(3):387-97. doi: 10.1161/CIRCULATIONAHA.106.634949.

187. Matouk AI, Taye A, El-moselhy MA, Heeba GH, Abdel-rahman AA. Abnormal cannabidiol confers cardioprotection in diabetic rats independent of glycemic control. Eur $\mathrm{J}$ Pharmacol. 2018;820:256-264. doi: 10.1016/j.ejphar.2017.12.039.

188. Gall B, Parkhouse W, Goodman D. Heart rate variability of recently concussed athletes at rest and exercise. Med Sci Sports Exerc. 2004;36(8):1269-74.

189. Paniccia M, Verweel L, Thomas SG, et al. Heart rate variability following youth concussion: how do autonomic regulation and concussion symptoms differ over time postinjury? BMJ Open Sport Exerc Med. 2018;4(1):e000355. doi: 10.1136/bmjsem2018-000355.

190. Counihan PJ, Fei L, Bashir Y, Farrell TG, Haywood GA, McKenna WJ. Assessment of heart rate variability in hypertrophic cardiomyopathy. Association with clinical and prognostic features. Circulation. 1993;88(4 Pt 1):1682-90. doi: 10.1161/ 01.cir.88.4.1682.

191. Conder RL, Conder AA. Heart rate variability interventions for concussion and rehabilitation. Front Psychol. 2014;5:890. doi: 10.3389/fpsyg.2014.00890.

192. Esterov D, Greenwald BD. Autonomic dysfunction after mild traumatic brain injury. Brain Sci. 2017;7(8):E100. doi: 10.3390/brainsci7080100

193. Gonca E, Darici F. The effect of cannabidiol on ischemia/reperfusion-induced ventricular arrhythmias: the role of adenosine A1 receptors. J Cardiovasc Pharmacol Ther. 2015;20(1):76-83. doi: 10.1177/1074248414532013.

194. Twitchell W, Brown S, Mackie K. Cannabinoids inhibit N- and P/Q-type calcium channels in cultured rat hippocampal neurons. J Neurophysiol. 1997;78(1):43-50. doi: 10.1152/ jn.1997.78.1.43.

195. Ross HR, Napier I, Connor M. Inhibition of recombinant human Ttype calcium channels by Delta9-tetrahydrocannabinol and cannabidiol. J Biol Chem. 2008;283(23):16124-34. doi: 10.1074/ jbc.M707104200.

196. Galve-Roperh I, Aguado T, Palazuelos J, Guzman M. The endocannabinoid system and neurogenesis in health and disease. Neuroscientist. 2007;13(2):109-14. doi: 10.1177/1073858 406296407.

197. Beale C, Broyd SJ, Chye Y, et al. Prolonged cannabidiol treatment effects on hippocampal subfield volumes in current cannabis users. Cannabis cannabinoid Res. 2018;3(1):94-107. doi: 10.1089/can.2017.0047.

198. Aguado T, Palazuelos J, Monory K, et al. The endocannabinoid system promotes astroglial differentiation by acting on neural progenitor cells. J Neurosci. 2006;26(5):1551-61. doi: 10.1523/ JNEUROSCI.3101-05.2006.

199. Rueda D, Navarro B, Martinez-Serrano A, Guzman M, GalveRoperh I. The endocannabinoid anandamide inhibits neuronal progenitor cell differentiation through attenuation of the Rap1/BRaf/ERK pathway. J Biol Chem. 2002;277(48):46645-50. doi: 10.1074/jbc.M206590200.

200. Wallace J, Covassin T, Nogle S, Gould D, Kovan J. Knowledge of concussion and reporting behaviors in high school athletes with or without access to an athletic trainer. J Athl Train. 2017;52(3):228-35. doi: 10.4085/1062-6050-52.1.07

201. McCrory P, Meeuwisse W, Dvorak J, et al. Consensus statement on concussion in sport-the 5th international conference on concussion in sport held in Berlin, October 2016. $\mathrm{Br} \mathrm{J}$ Sports Med. 2017;51(11):838-47. doi: 10.1136/bjsports-2017097699. 